\title{
Editorial
}

\section{TOURISM IN A RURAL SETTING: NEW DIRECTIONS AND CHALLENGES}

The origins of this special issue lie in the working group on rural tourism at the ESRS congress in Vaasa, Finland in August 2009. With one exception, the issue comprises revised papers from that conference supplemented by this introductory article.

\section{Why a Focus on Rural Tourism?}

Rural tourism is important throughout the world, and it is likely to become even more important as it is regarded as one of the fastest growing market segments of tourism [1]. What fuels it is several developments on the visitor side, such as: consumer orientations away from mass tourism, a growing demand for activity-based holidays, growth in the short breaks holiday market, a move towards healthier lifestyles, and possibly a wish to re-experience one's rural childhood or the heritage of one's ancestors [1]. Rural tourism offers a varied range of products and thus attracts visitors from various segments of the population [2].

The growth in rural tourism may be understood not only from changes on the visitors' side, but also from processes going on in rural areas. Countries around the globe are going through processes of rural restructuring and decline, particularly as part of the transition from Fordist to post-Fordist methods of agricultural production. Many resource-based communities are facing economic crisis and large out-migration: farm incomes have fallen, agricultural employment has diminished, rural populations have aged and become smaller, and local services such as shops, schools, libraries have declined.

In contrast to the rural world which faces challenges of decline, tourism presents a picture of thriving growth. The question is whether rural areas can profit from the general growth potential of tourism. Tourism as an alternative source of income is thought to play a central role within areas undergoing restructuring. Many local actors and national tourism administrations have turned to tourism for new economic activities and diversification of the countryside. The combination of tourism and rural development may thus point to a counter trend for rural areas where new knowledge, economic resources and people will be contributing.

The rural tourism literature has had a strong focus on growth and change and on the influential role of tourism in local and regional development. Increasingly, emphasis has been put on changes in consumer preferences, markets, technology and competitiveness. The competitiveness of tourism firms depends in large part on their innovativeness to introduce new products and meet the requirements of potential customers. As a result, the products of tourism are constantly being modified. Hall and Williams [3] point out that it is rather puzzling that so little research has been concerned with what is behind this growth. Hopefully, the articles in this issue will shed some light on the processes that are central to growth in rural tourism, and present examples of such change.

\section{What is Rural Tourism?}

Rural tourism is a complex and diverse area. There are many types of enterprises, many different policy initiatives, and many understandings that may be in focus. While rural areas have been the setting for recreation and tourism for a long time, such activities have not always been branded as rural. A growing awareness of the qualities of the rural as products of tourism, has transformed tourism in rural settings from a minor and rather passive element to become an active and significant agent of change [4]. The level of participation in rural tourism has increased, and the range of activities has also expanded dramatically [5].

As a consequence, what constitutes rural tourism may be hard to define. The two terms: 'rural' and 'tourism' are both fairly broad with many meanings. When rural researchers study rural tourism, they tend to see it as diversification of the countryside and an important feature of multifunctional agriculture. Tourism researchers on the other hand, see it as a special, although growing, segment of the industry. The two approaches fragment the field. A further complication is that 'rural tourism' is often 
used inter-changeably with terms such as green tourism, eco-tourism, nature-based tourism, agritourism, or even adventure tourism.

Rural tourism depends on a wide range of natural and cultural resources. The comparative advantage of rural areas in tourism is rooted in features of the natural, cultural and social environments. It is dependent on 'countryside capital' such as wildlife, rural settlements and local cultural traditions [6]. Several articles in this issue describe what resources can be made into attractive tourism products.

In the branding of tourism as rural, one pertinent question becomes what constitutes the rural? In popular conceptions the rural stands out with a variety of meanings, from that which is utterly idyllic to that which is scary and oppressive. It is therefore not as simple as seeing rural tourism as tourism that takes place in the countryside - even if in its most practical sense, 'rural' refers to those particular spaces that are not urban. A concise framing of the rural is made difficult by the rapid changes of the countryside which represent shifts in its manifestations, and which blur the distinction between country and city [7]. Some areas are distinctly rural, but may display characteristics of urbanity and vice versa. The rural as a cultural specificity seems to have become anachronistic. As seen from the academic debate on the topic recent decades, conceptualizations have shifted from the urban-rural dichotomy, to distinguishing the rural through demographic and geographic means, to defining it through the existence of particular industries such as agriculture and fishery. The 'cultural turn' in rural studies changed the emphasis again from trying to define the 'real' rural to understanding the multiple narratives of the rural. In the 1990s ideas and discourses of the rural became the new focus for understanding on what basis people act out the rural. The ways in which the rural has been constructed and constituted in terms of tourism are often found in terms of the marketing and packaging of destinations, events and activities embedded in pictures of peace and quiet, landscape, nature and wilderness. In other words, what it is about the rural that is marketed to attract visitors has to do with its symbolic notions. To complicate it further, as some have done, the symbols of rurality are increasingly becoming 'deterritorialized' - ie detached from real rural space [7, 8].

\section{Innovation within Rural Tourism}

All the articles in this issue deal with innovation within rural tourism in some way or other. Innovation has for long been a largely neglected field in tourism research in general. It has gained increasing attention since the late 1990s when the field was opened up for studies $[9,10]$. However, tourism innovation is seen as a rather specialist topic which is relatively isolated both from tourism studies as such and social science research on innovation [3,11]. A pervasive finding of innovation research in tourism is that innovative activity is low, and even non-existent in the small firms [11]. One should, however, be careful when generalizing empirical findings on innovation in tourism. The industry is diverse and it is subject to economic, political and geographical differences [12].

As a concept 'innovation' is an elusive term, and as a phenomenon it may be defined and classified in many ways. Generally speaking, it is connected to newness: new products, new methods of production, new markets, and new organizational forms. In order to be differentiated from an 'idea', an innovation needs to be implemented. Although the definition focuses on newness, it does not seem to require that a major breakthrough happens nor that it is new at a world level. Innovation activity may be regular and incremental, and its impact range may be very local.

Possibly due to the historical belief that manufacturing is the main driver of economic change, the service sector in general has not been regarded very much as a site of innovation. The extent to which services are similar to or distinctive from manufacturing has been debated, and there seems to be a consensus that the service sector is distinctive in ways that bear influence on its innovation activity [3]. From the literature it is possible to identify several distinctive features of service/tourism products. One is the co-terminality of production and consumption. In tourism the products are intangible and produced and consumed simultaneously. Customers are part of the production, and production and consumption of the products happen with both producers and consumers present [13]. In this way customers may be important sources of new ideas.

In a competitive market, service quality is becoming more and more important for survival of firms. And, because customer experiences are so important in tourism, innovation is likely to focus on quality [3]. The quality of the product depends much on the quality of the interaction between customers and suppliers. It is for instance the memory of a good experience that is of value for customers. This means that skills and competences - the human factors, are of great importance. As seen in some of the articles in this issue, in the hospitality sector, the product is to a great extent characterized by inter-personal relations, 
embodied performances, impression management and identity construction, features that will all make their mark on innovation processes.

A last special feature of service- and tourism innovation to be mentioned here is that organizational innovations are considered particularly important. Organizational innovations may be novel ways of initiating, carrying out, sharing, and spreading innovations. As shown in the article by Kvam and Stræte, this may be more or less informal cooperative measures or networks and clusters, for instance to develop markets, but it may also be to overcome resource shortage and to combine different knowledges. These types of organizational distinctivenesses are not uniformly present in all firms, and they may be combined in different ways.

Since the focus in this issue is on rural tourism, we may narrow down the subject even further, and ask what are the distinctive characteristics of rural tourism that may influence innovation? On the list of barriers one may put that rural tourism firms are often small; they are family based, and have scarce access to capital and knowledge. They are local and often developed from farms. A further factor may be what Endensor [14] has pointed out, that "...the rural realm (..) is assigned significance as that which remains the same in a changing world..." ( $p$ 485). So, can we expect a realm that is understood as stable and fixed to be a platform for innovation? Here, the dynamics between old and new becomes especially interesting. Brandth, Haugen and Kramvig illustrate how this happens when traditions and traces of past rural/farm life is commercialized into new tourism products. Schmitt's article links to the theoretical approach of 'creativity of action' to highlight how the peasant principle stimulates farming families to become drivers of rural development. It is part of the peasant principle to create, stabilize and expand the resource base of the farm, and thus diversification and pluriactivity is an innovative principle in these types of firms.

A further characteristic of rural tourism which may influence innovation is that many of the enterprises offer activities that qualify for belonging to the experience based sector. Mountain climbing, sea-fishing, rafting, canoeing, dog-sledding and various cultural events are experiences that are additions to many other types of products. Experience based firms have been found to have a high level of innovation [15]. This aspect runs counter to what is considered to hinder innovation in rural tourism.

\section{The Articles}

The questions that are relevant to raise in this introduction are what characterises and what fosters innovation and development in small, rural firms? Research on innovation in small-scale, rural tourism firms is rare. The articles in this special issue thus produce knowledge that ought to be in demand. Moreover, as many tourism firms are located in rural areas and are included in studies on tourism more generally, the knowledge presented here may also be of interest to researchers on innovation in tourism more generally. Rønningen reports from a Norwegian survey and finds that contrary to expectation, innovative activity in the rural tourism firms is quite high. As a matter of fact, it is slightly higher than within tourism firms in general. Rural firms that give priority to obtaining information from external sources, for instance about markets, and firms that put priority on increasing employee competence, are more innovative than other rural firms.

Cooperation has generally been seen as a remedy for increasing innovations. Rønningen's study confirms this and finds that enterprises that participate in cooperation are more innovative than others. He finds that cooperation is particularly important for market innovation, something that may give grounds for recommendations: firms that need to innovate should attempt to improve their networks and relationships with other firms or relevant actors. Examples of how this may happen are provided by Kvam \& Stræte who in their article show more of the mechanisms at work. They point out that the role of a mediator between cooperating firms seems to be important, for instance when it comes to common booking channels and standards of quality.

The question asked in Kvam \& Stræte's article is what the drivers of innovation are in nature-based tourism. While competition is generally seen as one of the important drivers of innovation, Kvam and Stræte emphasise cooperation. The result is not so much new products never commercialised before, as new combinations of products. The clue in this process is to find new partners. In addition to innovation, they stress the role of diffusion in tourism development. In sea fishing tourism, which is their case, innovations in one area are spread to another thus forging new development in several regions. Taken together the two concepts, innovation and diffusion, show a more complete picture of the process. 
Two of the articles focus on agritourism -tourism based on farming in Germany and Norway. The question is what are the conditions for innovation in this sector that, generally speaking, is considered very traditional. Both articles show how tourism develops from what van der Ploeg [16] terms 'peasant mode of farming' which contrasts with the 'entrepreneurial mode of farming.' Among the characteristics of peasant farming is that it is multifunctional rather than specialized, that it builds on craft and skill-oriented technologies, and that there is continuity between past, present and future (p. 114). All these characteristics are among the aspects that induce innovation in farm based firms.

Brandth, Haugen and Kramvig emphasise three central aspects of tourism innovation in their article on farm tourism. The first aspect may at first seem like a challenge to the focus on newness in innovation. It is the importance of traditions and conventions in generating new products. In the case of farm tourism, heritage and what connects to the past is central in the process of creating new products. The second aspect is the relational character of farm tourism innovation, particularly the participation of customers in the creative process of new product development (cf customer made development), but also relations to family members and people with valuable knowledge of various kinds. The article points to the interaction between the tourist host and the local community where the moral economy of the farmer tourist hosts might be a special feature of innovation in rural areas where the sustainability of social relations is said to be particularly important. Lastly, the article shows that innovations are incremental and rarely represent radical breakthroughs; they are more continuous add-ons. The process is slow and newness may not lie with the product components themselves, but in the way they are combined.

Mathilde Schmitt's article draws on a unique longitudinal data set, which allows analysis over a thirty year span of the relationship between agritourism and rural development. It focuses on farm families who are seeking to survive by innovation and diversification into tourism, and it discloses the existence of two separate paths that have been pursued. Some families have made tourism their main livelihood, while it represents an additional source of income for others. Schmitt's article is the only one, which explicitly focuses on women's agency and their contributions to the development of farm tourism in a period when farm production is decreasing. Although the decision to diversify is made by the household, it is the women who carry out the tourist work in addition to their farm-, care- and other housework. Often a new non-agricultural service was introduced as an initiative from newly arrived daughters-in-law who had a good education and work-experience from other sectors of the economy. The article shows how farm families respond to ongoing rural development processes, and how they in the process sustain and transform not only their self-perception, but also the countryside of which they are a part.

Nearly all articles deal with the definition of innovation. Both Rønningen and Kvam \& Stræte search the literature for definitions that can be operationally applied. The very fact that they find this to be necessary, shows the broad and unstable character of the concept. Brandth, Haugen and Kramvig, who study innovation from a phenomenological perspective, argue that the concept has more in common with improvisations than with any planned process with a definite goal in sight. Ideas pop up by chance. Because ideas are relatively limited in the beginning and not subjected to much economic and social risk, they are implemented step-by-step, by trial and error. Both articles on farm tourism show that farmers innovate not only to develop their business, but also to sustain their farms as small-scale, household based enterprises. The future is constructed by means of available resources created in the past, remade by the creative and innovative capacity of the individual.

\section{Berit Brandth}

(Guest Editor)

Department of Sociology and Political Science

Centre for Rural Research

Norwegian University of Science and Technology

N-7491 Trondheim, Norway

Tel: +4773592285

Fax: +4773591564

E-mail: beritb@svt.ntnu.no 


\section{REFERENCES}

[1] Brown F, Hall D. Eds. Tourism in Peripheral Areas. Clevedon: Channel View Publications 2000.

[2] Blekesaune A, Brandth B, Haugen MS. Visitors to farm tourist enterprises in Norway. Scandinavian J Hosp Tourism 2010; 10(1): 54-73.

[3] Hall MC, Williams AM. Eds. Tourism Innovation. New York: Routledge 2008.

[4] Hall D, Roberts L, Mitchell M. Eds. New Directions in Rural Tourism. Aldershot: Ashgate 2005.

[5] Sharpley R, Sharpley J. Rural Tourism: An Introduction. London: Thomsom Business Press 1997.

[6] Garrod B, Wornell R, Youell R. Re-conceptualising rural resources as countryside capital: The case of rural tourism. J Rural Stud 2006; 22: 117-128.

[7] Cloke P. Conceptualizing Rurality. In: Cloke P, Marsden T, Mooney PH. Eds. Handbook of Rural Studies. London: Sage 2006; pp. 18-28.

[8] Halfacre K. Locality and social representation: Space, discourse and alternative definitions of the rural. J Rural Stud 1993; 9: 1-15.

[9] Hjalager AM. Agricultural diversification into tourism. Tourism Manage 1996; 17(2): 103-11.

[10] Hjalager AM. Innovation patterns in sustainable tourism. An analytical typology. Tourism Manage 1997; 18(1): 35-41.

[11] Hjalager AM. Repairing innovation defectiveness in tourism. Tourism Manage 2002; 23: 465-74.

[12] Sundbo J, Orfila-Sintes F, Sørensen F. The innovatiove behaviour of tourism firms - Comparative studies of Denmark and Spain. Res Policy 2007; 36: $88-106$.

[13] Crang P. Performing the tourist product, in Touring cultures. Transformations of travel and theory. In: Rojek C, Urry J, Eds. London: Routledge 1997; pp. 137-154.

[14] Edensor T. Performing rurality. In: Cloke P, Marsden T, Mooney PH, Eds. Handbook of Rural Studies. London: Sage 2006; pp. 484-95.

[15] Sundbo J, Sørensen F, Fuglsang L. Innovation in the experience sector. [http://diggy.ruc.dk/bitstream/1800/3978/2/ Innovation_in_the_experience_sector.pdf] undated [cited 2009 Nov. 20]

[16] van der Ploeg JD. The New Peasantries. Struggles for Autonomy and Sustainability in an Era of Empire and Globalization. London: Earthscan Ltd. 2008.

(C) Berit Brandth; Licensee Bentham Open.

This is an open access article licensed under the terms of the Creative Commons Attribution Non-Commercial License (http: //creativecommons.org/licenses/by$\mathrm{nc} / 3.0 /$ ), which permits unrestricted, non-commercial use, distribution and reproduction in any medium, provided the work is properly cited. 